\title{
Depression in Children and Adolescents
}

\author{
Claudia Mehler-Wex, Michael Kölch
}

\begin{abstract}
SUMMARY
Introduction: Prevalence rates for depression in children and adolescents are estimated up to $8.9 \%$. Symptoms in this age group are different from those of depression in adults. Both neurobiological and psychosocial factors are involved in its development.
\end{abstract}

Methods: Selective literature review.

Results: Of note are both the high rate of spontaneous remissions in childhood (33\%), and the high rate of depressions continuing into adulthood ( $80 \%$ ). In addition far fewer evidence based treatments are available than for adults. Fluoxetine is currently the only medication licensed for use in children and adolescents for this indication. Tri- and tetracyclic antidepressants have not been shown in meta-analyses to be effective in children and adolescents. Most antidepressants lead to age related side effects, including attention deficit and in particular behavioral toxicity, which has to be taken seriously wherever there is a suicide risk.

Discussion: The treatment of depression in childhood and adolescence should be based on multimodal interventions including psychotherapy, including cognitive behavioral therapy, which has proven effectiveness, psychosocial interventions and medications in severe cases. Patients with severe depression, especially suicidal minors, should be treated in patients units.

Dtsch Arztebl Int 2008; 105(9): 149-55 DOI: 10.3238/arztebl.2008.0149

Key words: depression, pediatric disease, mental disorder, suicide, serotonin reuptake inhibitor

$\overline{\text { Klinik für Kinder- und Jugendpsychiatrie/Psychotherapie, Universität Ulm: Prof. }}$ Dr med. Mehler-Wex, Dr. med. Kölch
$T$ he younger the patients, the greater the differences in depressive symptoms in minors to the classic symptoms in adults. In the ICD-10, depression is classified among the affective disorders (F3). Depending on its severity, depression is subcategorized into mild, moderate, and severe depressive episodes or recurrent depressive disorders, which may be accompanied by psychotic symptoms. Such psychotic symptoms in minors manifest primarily as ideas of sinfulness, guilt, or failure. Depressive symptoms have to be present for a minimum of two weeks; a relapse/recurrence is diagnosed after a symptom-free interval of at least two months. Underlying organic or psychological/mental disorders and misuse of psychotropic substances will have to be excluded as the primary cause; prior maniform episodes point to a diagnosis of bipolar disorder. The cardinal symptoms of depression are listed in box 1 .

In minors, depressive symptoms are strongly dependent on the patient's age (table 1). In the sense of "masked" depression, toddlers will mostly present with somatic symptoms such as loss of appetite, sleeping problems, failure to thrive, and developmental disorders or stomach pain, but no organic cause can be established (e1). After an initial period with screaming and crying, such children may become increasingly more passive and apathetic. In preschool children, the main symptoms include reduced psychomotor activity, listlessness, mood swings, irritability, and aggressiveness. School age children report sadness, ideas of guilt, or fear of failure and withdraw from social contacts. Sometimes, suicidal ideation occurs for the first time. In adolescents - similar to adults - the main problems include achievement/performance problems, withdrawal, loss of drive and interests, as well as fear of the future, problems with self esteem, and sometimes suicidality. Irritability, a low frustration tolerance, violent temper, and externalizing and histrionic behavior may also be manifestations of depression in adolescence. Phobias and compulsive activities may occur concomitantly or become more pronounced. Because of non-participation in age appropriate everyday life, developmentally necessary stimuli and maturation may be lacking, with resultant developmental delays in linguistic, (psycho)motor, cognitive, and social abilities, which in turn lead to further loss of feelings of self esteem and self confidence. If the disorder takes a chronic course, substance misuse and suicidality may ensue (table 1). 
BOX 1

\section{Symptoms of depression according to ICD-10}

\section{Main symptoms of depression}

- Low mood, most of the time, almost daily, for a minimum of two weeks

- Loss of interests, joylessness, limited activity

- Lack of drive, easily fatigued, fatigue

\section{Possible further symptoms}

- Cognitive impairments (concentration, attention), indecisiveness or hesitation

- Reduced feelings of self esteem, low self confidence,

feelings of worthlessness

- Inappropriate feelings of guilt, self reproach

- Psychomotor agitation or inhibition

- Suicidal thoughts, suicidal behavior

- Disrupted sleep

- Loss of appetite or increase in appetite with change in weight

\section{Suicidality}

Suicidality as a severe problem of depression can also affect minors; often this is preceded by a presuicidal phase (table 2). The lifetime prevalence of suicide attempts in children and adolescents is estimated to be $3 \%$ to $4 \%$. Although decreasing rates have been reported in the industrialized nations in the past few years, these are likely to rise again as a result of warnings about, and therefore reduced prescribing of, selective serotonin reuptake inhibitors (SSRIs) (e2). For Germany, this trend cannot be confirmed so far (e3). Important risk factors include psychological/mental disorders, suicides or premature death in a close relative, as well as performance/achievement problems (e4). Parasuicidal acts and suicidal thoughts are notably more common in girls (10\% to $35 \%$ ), but boys successfully commit suicide three times as often (1). Suicide attempts that have been planned for a long time, planned in precise detail, and executed with equal precision require such protective measures as are offered only in intensive inpatient therapy (table 2).

\section{Epidemiology}

Prevalence data on depressive disorders in Western industrialized nations range from $1.9 \%$ to $3.4 \%$ for primary school children, $3.2 \%$ to $8.9 \%$ for adolescents, and $8 \%$ to $25 \%$ for clinical samples. From the 13 th year of life, depression is significantly more common (2). Depressive episodes during adolescence are often of a shorter duration than in adulthood; in one third, remission occurs within three months. In up to $80 \%$, latent persistence and high recurrence rates can be expected: $25 \%, 40 \%$, and $72 \%$ relapse after 1,2 , or 5 years, respectively (2).

\section{Etiology}

The development of depression has a multifactorial explanation. Genetic, neurobiological, somatic, peristatic, and personality related factors have a role. External stress factors may induce, by means of "biological priming" (3), neurobiological changes that increase vulnerability, e.g., increased excretion of catecholamine or cortisol, or cerebral atrophy. The influence of environmental factors as a trigger for depression is higher the younger the patient.

\section{Neurobiology}

Most neurobiological findings relating to depression come from studies in adults. A potential genetic component is supported by the higher concordance rates of monozygotic twins and the risk increase of up to $50 \%$ if the parents suffer from depression (4). Hereditability of severe and early onset depression is particularly high (4).

Involvement of a serotonin deficiency syndrome in the pathogenesis of depression is supported by numerous findings, including a lowered concentration of serotonin metabolites in the cerebrospinal fluid of depressive patients or the fact that inhibition of the serotonin synthesis induces depressive symptoms (4). Postmortem examinations in depressive persons have also found significant reductions in serotonin transporters in different parts of the brain and a presumably compensatory, raised postsynaptic density of serotonin receptors (5).

Lowered concentrations of norepinephrine metabolites have also been associated with depressive symptoms (5). A common effect of the monoamines may be due to activation of the brain-derived neurotrophic factor (BDNF) with stimulation of the hippocampal neurogenesis.

Neurogenesis in the hippocampus on the other hand can result in disruptions to cell structure and function, owing to the stress-related release of glucocorticoids during depression (6). The hypothesis that dopaminergic transmission is involved is given credence by the fact that dopamine reuptake inhibitors and substances that inhibit the degradation of dopamine - e.g., monoaminoxidase inhibitors - may have antidepressant effects (5).

Neuroendrocrinologically, disorders of the hypothalamic-pituitary-adrenal axis, accompanied by increased secretion of cortisol, have been postulated. Birmaher et al. showed in a study that $54 \%$ of the depressed minors who were examined had a pathological dexamethasone test result (7); additionally, cortisol hypersecretion in the evening and the morning release of dehydroepiandrosterone (DHEA) correlated with the severity of the depression (8). In depressive adults, a reduced release of growth hormone was found in the initial hours of sleep, whereas in children the secretion was raised (9). Substance $\mathrm{P}$ antagonists were also found to have antidepressant effects (10). Substance P is co-located with monoamines in the limbic system and the spinal cord.

MRI scans in depressive children have shown a reduced volume of the frontal cortex and an expansion of the lateral ventricles (11). Hypometabolism in the areas of the frontal and temporal cortex has been described (12). The sleeping patterns of depressive patients are characterized by shortened circadian periods and shortened REM (rapid eye movement) latency (13). 
TABLE 1

Age dependent signs of depression (modified from 4, 14, 19)

\begin{tabular}{|c|c|c|}
\hline Age group & Psychopathological & Somatic \\
\hline Toddlers & $\begin{array}{l}\text { Screaming, restlessness, crying; } \\
\text { Disinterestedness, passivity, apathy, lack of expression; } \\
\text { Unprompted crying attacks, irritability, and agitation; } \\
\text { Reduced creativity, imagination, and stamina; } \\
\text { Clinginess; } \\
\text { Silliness; } \\
\text { Autostimulating behavior }\end{array}$ & $\begin{array}{l}\text { Disruptions to falling asleep/sleeping through because of } \\
\text { insufficient self calming strategies, eating disorders and } \\
\text { refusal to eat accompanied by weight loss, increased } \\
\text { proneness to infections ("malingering") }\end{array}$ \\
\hline $\begin{array}{l}\text { Preschool } \\
\text { children }\end{array}$ & $\begin{array}{l}\text { Crying, irritability, aggressive outbreaks, } \\
\text { proneness to explosive outbursts; } \\
\text { Hypomimia, reduced gestural activity/passive general } \\
\text { motor response, introversion, lack of interest; } \\
\text { joylessness; } \\
\text { Irritability, low frustration tolerance, aggressiveness; } \\
\text { Delayed social and cognitive developments; } \\
\text { Attention seeking behaviors; } \\
\text { Autostimulation }\end{array}$ & $\begin{array}{l}\text { Secondary enuresis/encopresis, } \\
\text { regressive use of language, } \\
\text { delays in motor development, } \\
\text { sleeping and eating disorders }\end{array}$ \\
\hline $\begin{array}{l}\text { School- } \\
\text { children }\end{array}$ & $\begin{array}{l}\text { Crying, defiant behavior, defense, } \\
\text { (auto-)aggressive behaviors; } \\
\text { Self reported sadness, listlessness and lack of drive, } \\
\text { disinterestedness, withdrawal; } \\
\text { Problems concentrating, failure at school; } \\
\text { Worries, initial thoughts expressing tiredness of life; } \\
\text { Attention seeking }\end{array}$ & $\begin{array}{l}\text { Sleeping and eating disorders, } \\
\text { somatic complaints, } \\
\text { regressive behavior }\end{array}$ \\
\hline Adolescents & $\begin{array}{l}\text { Apathy, despair, anger, inappropriate affect, refusal, } \\
\text { listlessness and lack of drive, disinterestedness, } \\
\text { withdrawal; } \\
\text { Thoughts and actions slowed down, problems in } \\
\text { performance/achievements, cognitive impairments; } \\
\text { Apathy, anxiety, disgust, lack of self confidence, } \\
\text { self reproachfulness, brooding, fear of the future, } \\
\text { suicidality }\end{array}$ & $\begin{array}{l}\text { Sleeping and eating disorders, } \\
\text { psychosomatic complaints, } \\
\text { low morning mood, } \\
\text { early waking, } \\
\text { inability to relax and rest }\end{array}$ \\
\hline
\end{tabular}

\section{Psychosocial factors}

The most important psychological models of depression are based on Beck's cognitive theory, according to which the thoughts of depressive people are characterized by a negative fixation on themselves, the world, and the future. Seligmann developed the theory of acquired helplessness, which says that because of learning experiences, depressive people are convinced that they are exposed to events they cannot influence and are helpless. This is associated with feelings of powerlessness and low self esteem. According to Lewinsohn, the amplifier-loss hypothesis has a crucial role in depression. A lack of positive feedback may lead to a reduction in positive actions and increasing loss of motivation (e5). Deficient problem solving skills and dependent personality traits are also risk factors for depression in children and adolescents. A primarily aggressiveimpulsive style of action - e.g., in the context of attention deficit and hyperactivity disorder - leads to the development of secondary depression after numerous conflicts in $30 \%$ of cases (14).

Dysfunctional interaction between parents and children are characterized by deficits in parental emotionality. The discrepancy between the child's expectations and the ambivalent-uncontrollable reaction of the parents result in stress, frustration, and possibly depression. Critical life events have been found to be premorbid risk factors in $70 \%$ of depressive children and adolescents (14). The most important stress factors in children and adolescents with depressive disorders are (15):

- Loss of a parent

- Conflict in the relationship between the parents, and divorce

- Single parenthood

- Mental or physical illness in a parent

- Deprivation, long-term separations in the first year of life

- Low social status, migration.

Chronic stresses such as problems in social relationships, a lack of friendships and attention, subjective experience of low attractiveness, excessive, or insufficiently high, demands at school, a change in school, or learning disorders can also trigger depression (16).

\section{Diagnosis}

The basis of the diagnosis is a detailed history of symptoms as well as a developmental and family history of the patient and the people close to him or her, in which familial stresses are elicited. In the child, dissimulative tendencies or feelings of shame are common; verbal and introspective skills are often immature, so that nonverbal methods such as drawing or projective methods, e.g., sentence completion tests, are of diagnosticexplorative importance. 
TABLE 2

\section{Warning signs of suicidality (modified from 14)}

\begin{tabular}{|c|c|}
\hline Interaction & $\begin{array}{l}\text { Social withdrawal } \\
\text { Thoughts of death hinted at } \\
\text { Giving away personal effects } \\
\text { Sorting out outstanding matters }\end{array}$ \\
\hline Behavior & $\begin{array}{l}\text { Tendency to self neglect } \\
\text { Obvious, untypical changes in behavior } \\
\text { Neglectfulness regarding obligations and everyday life } \\
\text { Substance misuse }\end{array}$ \\
\hline Psychopathology & $\begin{array}{l}\text { Depressive symptoms } \\
\text { Incessant brooding } \\
\text { Dip in performance/achievements } \\
\text { Intense thoughts about death } \\
\text { (drawings, reading, poems, chatrooms, etc) } \\
\text { Suddenly relaxed mood after depressive phase } \\
\text { (suicide as a tension alleviating idea) }\end{array}$ \\
\hline Alarm signal & $\begin{array}{l}\text { Letter saying goodbye } \\
\text { Concrete plans to commit suicide } \\
\text { Previous serious suicide attempts }\end{array}$ \\
\hline
\end{tabular}

Fundamentally, organic causes such as cerebroorganic symptoms, postinfectious depression, endocrinological disorders (e.g., thyroid function disorders) have to be excluded. A physical-neurological examination, laboratory tests, and a medical history are also required. This includes information on regular medication and the question of substance misuse as possible triggers of depression.

One component of routine diagnostics should be assessment of intelligence to exclude excessive or insufficient demands placed on the patient at school, as well as age-specific depression questionnaires. In addition to the psychiatric main diagnosis, axes II to VI of the multiaxial classification scheme (17) (table 3) complement the diagnosis in minors.

\section{TABLE 3}

Multiaxial classification scheme (from 17)

\begin{tabular}{l|l} 
Axis & Content \\
\hline I & Clinical-psychiatric syndrome \\
\hline II & $\begin{array}{l}\text { Circumscribed developmental disorders } \\
\text { (dyslexia, maths dyslexia, motor and linguistic developmental deficits, etc) }\end{array}$ \\
\hline III & $\begin{array}{l}\text { Intelligence level } \\
\text { (to exclude excessive demands made at school/in the job) }\end{array}$ \\
\hline IV & $\begin{array}{l}\text { Physical symptoms } \\
\text { (to exclude somatogenic depression) }\end{array}$ \\
\hline V & $\begin{array}{l}\text { Associated current, abnormal, psychosocial circumstances } \\
\text { (abnormal intrafamilial relationships, psychological/mental problems/ } \\
\text { deviant behavior or disabilities within the family, inadequate or distorted } \\
\text { intrafamilial communication, abnormal educational conditions, abnormal } \\
\text { immediate environment, acutely stressful life events, societal stress fac- } \\
\text { tors, chronic interpersonal stress with regard to school or work) }\end{array}$ \\
\hline VI & $\begin{array}{l}\text { Global assessment of psychosocial functioning } \\
\text { (9 stages: "exceeding social functioning" to "deep and pervasive social } \\
\text { impairments that require continual treatment") }\end{array}$ \\
\hline
\end{tabular}

\section{Differential diagnoses}

Other affective disorders, such as bipolar affective disorder (F31) and schizoaffective disorders (F25.1) will have to be excluded. A depressive symptom is also possible in adjustment disorders (F43), but an unequivocal temporal connection with a stressful experience is essential for this diagnosis. Anxiety disorders sometimes present as mood swings, withdrawal or avoidance tendencies, and physical unwellness. Important differential diagnoses in childhood are emotional disorders, whose course is milder, more focused, and characterized by disproportionate pathological expression of behaviors typical for the child's age (Emotional disorders with onset specific to childhood, F93, e.g., separation anxiety).

\section{Comorbidities}

Depressive disorders in minors are characterized by substantial comorbidity with anxiety disorders (up to $75 \%$ ), impaired social functioning (up to $50 \%$ ), and substance misuse and/or aggressiveness (25\%) (15). Especially the latter subgroup may be misdiagnosed because of externalizing symptoms, and serious suicide attempts may occur because of patients' increased impulsivity. Depressive symptoms often manifest as eating disorders, and compulsive disorders can accentuate or manifest in association with depression.

\section{Therapy}

The level of evidence for individual therapeutic interventions in depressive disorders may be high, but it is important to remember that many studies include only small sample sizes and the study conditions are not the conditions under which routine care is provided (e6). Therefore new insights into efficacy and long-term effects can be expected in the future. This does not amount to therapeutic nihilism - therapeutic measures for depressive disorders in minors should always be multimodal and be administered on an outpatient basis; inpatient treatment is required only in severe cases and suicidality (box). In inpatients, it will have to be ensured that remaining resources are being activated to a sufficiently high degree, because depression is often associated with a tendency to regression. Multimodal treatment entails psychotherapeutic, psychosocial, and, if required, pharmacotherapeutic interventions. In mild depression in children and adolescents, psychosocial treatment is the mainstay. This includes giving advice to the parents with regard to a more sensitive style of upbringing and the elimination of stress factors. In a moderate episode, drug treatment should be discussed, depending on the level of psychosocial functioning and the responsiveness to psychotherapeutic procedures; of importance here is the fact that in young people, the time factor is eminently important for psychosocial adaptation in school, vocational training/further education, and other areas. In severe depressive episodes, which by definition are accompanied by serious impairments (such as missing school, social withdrawal), accompanying treatment with antidepressants is advised (18) (box 2). 


\section{Psychotherapy}

Independent of the choice of psychotherapeutic method, the following general core objectives of depression therapy are:

- Reduction of stress factors

- Increasing positive activities

- Imposing a structure on everyday life

- Promoting, and raising awareness of, available resources

- Training in social competences

- Learning of problem solving strategies

- Modification of negative patterns of perception and interpretation

- Increasing self confidence and self esteem.

The level of evidence with regard to short-term and medium-term effectiveness in children and adolescents is highest for cognitive behavioral therapy (evidence level I), followed by interpersonal therapy (II) (e7, e8, e9, e10, e11). Hardly any empirical data are available for family therapy, client-centered play therapy, and psychoanalytical methods (19).

The focus of cognitive behavioral strategies is dealing with depression triggers, activation, learning problem solving, stress management and self management techniques, and modifying negative thought patterns. The focus of interpersonal therapy, which has also shown great benefits in adolescents, is on short-term, pragmatic, practical working through of interpersonal dysfunctions by administering training in interpersonal conflict resolution and social competences (4).

Family centered approaches are helpful in solving underlying conflicts, deficiencies/deficits, and dysfunc-
BOX 2

\section{Indication for inpatient treatment}

- Patients with severe depressive or psychotic symptoms

- Suicidal patients

- Patients with complex comorbidities

- Patients who cannot cope with attending school

- Patients who live in familial circumstances that particularly endanger children's welfare

- Patients who have not responded to outpatient treatment

tions at the relationship level. Establishing a strong, reliable relationship within the family, and strengthening the educational competences of the persons tasked with looking after/caring for the child is an important prerequisite for psychological stabilization. The younger the depressive child, the more important familial interventions. Where required, educational support from youth offices may be indicated.

\section{Pharmacotherapy}

Antidepressant drugs are subcategorized into several pharmacological classes, depending on the receptor profile; this also explains the range of adverse effects (table 4). Through different effective mechanisms, such as reuptake inhibition through transporter blockade or catabolic enzyme inhibition, the noradrenergic/serotonergic system is influenced. The effective latency of the selective serotonin reuptake inhibitors (SSRI) in spite of immediate serotonin transporter blockade implies that a

\section{TABLE 4}

Effective mechanism and receptor profile of modern antidepressant drugs with desired and undesirable effects (modified from 25)

\begin{tabular}{|c|c|c|c|c|c|c|c|c|c|c|c|}
\hline & \multicolumn{5}{|c|}{ SSRI } & \multirow{2}{*}{$\begin{array}{l}\text { SSNRI } \\
\text { VEN }\end{array}$} & \multirow{2}{*}{$\begin{array}{l}\text { SNRI } \\
\text { REB }\end{array}$} & \multirow{2}{*}{$\begin{array}{l}\text { NaSSA } \\
\text { MIR }\end{array}$} & \multirow{2}{*}{$\begin{array}{l}\text { DSA } \\
\text { NEF }\end{array}$} & \multicolumn{2}{|c|}{ Effects } \\
\hline & CIT & FLX & FLV & PX & SER & & & & & Desired & Undesirable \\
\hline NRI & & $+(+)$ & + & ++ & $+(+)$ & $+(+)$ & +++ & & $+(+)$ & Antidepressant & $\begin{array}{l}\text { Tachycardia, raised blood pressure, } \\
\text { headache, disrupted sleep, tremor, } \\
\text { restlessness, sweating, erectile/ } \\
\text { ejaculatory dysfunction }\end{array}$ \\
\hline SRI & +++ & +++ & +++ & +++ & +++ & +++ & & & $+(+)$ & $\begin{array}{l}\text { Antidepressant, } \\
\text { anxiolytic, } \\
\text { anti-compulsive }\end{array}$ & $\begin{array}{l}\text { Gastrointestinal problems, headache, } \\
\text { disrupted sleep, restlessness, } \\
\text { sweating, sexual dysfunction }\end{array}$ \\
\hline $\mathrm{H}_{1}$ & + & & & & & & & +++ & $(+)$ & - & Sedation, weight gain \\
\hline$M_{1}$ & & + & & $+(+)$ & & & & + & & - & $\begin{array}{l}\text { Constipation, urinary retention, } \\
\text { accommodative insufficiency, } \\
\text { tachycardia, cognitive problems }\end{array}$ \\
\hline$\alpha_{1}$ & & & & & & & & + & $+(+)$ & - & $\begin{array}{l}\text { Impaired orthostatic circulatory } \\
\text { responses, sedation }\end{array}$ \\
\hline$\alpha_{2}$ & & & & & & & & +++ & & Antidepressant? & Sexual dysfunction, priapism \\
\hline $5-\mathrm{HT}_{2}$ & & + & & & & & & +++ & +++ & $\begin{array}{l}\text { Antidepressant, } \\
\text { anxiolytic, } \\
\text { analgesic? }\end{array}$ & $\begin{array}{l}\text { Hypotension, sedation, } \\
\text { weight gain, } \\
\text { ejaculatory dysfunction }\end{array}$ \\
\hline
\end{tabular}

NRI, noradrenaline reuptake inhibition; SRI, serotonin reuptake inhibition; $H$, histamine receptor blockade; $M$, muscarinic receptor blockade; $\alpha$, adrenergic receptor blockade; $5-\mathrm{HT}_{2}$, serotonin receptor blockade; SSRI, selective serotonin reuptake inhibitors; SSNRI, selective noradrenaline and serotonin reuptake inhibitors; SNRI, selective noradrenaline reuptake inhibitors; NaSSA, noradrenergic and specific serotonergic antidepressants; DSA, dual serotonergic antidepressants; CIT, citalopram; FLX, fluoxetine; FLV, fluvoxamine; PX, paroxetine, SER, sertraline; VEN, venlafaxine; REB, reboxetine; MIR, mirtazapine; NEF, nefazodone 
cascade of adaptive processes leads to the antidepressant effect. This is primarily mediated through desensitization of the 5-HT1A and 5-HT1D receptors (5-HT = 5-hydroxytryptamine, synonym for serotonin), and secondarily through an increased firing rate of the serotonergic neurons (5). Since the breakdown of antidepressants involves different enzymes of the cytochrome (CYP)-P450 system, therapeutic drug monitoring of serum concentrations makes sense, especially if no effects are seen and if co-medications are given (20). In most cases, antidepressants result in inhibition of CYP enzymes, which may lead to lower metabolization of other medical drugs, raised concentrations to the level of intoxication, and increased adverse effects. Only Saint John's wort (hypericum) induces CYP3A4, which means that other substances can be metabolized more quickly and become ineffective. These pharmacokinetic interactions should be considered. In the case of drug therapy, comprehensive information should be provided - including about the licensing status - and close-knit monitoring of the patient is a must.

Because of non-proved effectiveness and because of the high risk of intoxication - especially fatal cardiac sequelae - tricyclic antidepressants are not indicated for depression in children and adolescents (18). New antidepressants (selective serotonin and noradrenaline reuptake inhibitors, SSRI and SSNRI) are not licensed for use in youngsters and are therefore mostly used "off label." SSRIs have an age dependent range of adverse effects; the activation syndrome is two to three times higher in minors than in adults - feared because of the potentially increased risk of suicide (21). Warnings issued by the Food and Drug Administration and the European Medicines Agency with regard to the use of antidepressants in minors have to be regarded critically, after analyzing available study data in greater detail (e12). The risk of suicidal ideation is raised in adolescents being treated with SSRIs, not the risk of suicide (22). Further adverse effects of SSRIs include nausea, loss of appetite, headaches, sleep disturbances, and sexual dysfunction.

Proof of efficacy and a license for fluoxetine currently exist for children from the age of 8 , which is partly due to the TADS study funded by the National Institute of Mental Health $(23,24)$. This study has shown the superiority of fluoxetine compared with placebo and relatively small effects of additional cognitive behavioral therapy (CBT) in minors under medication; the additional CBT is said to reduce suicidality (18). Contrary to this result, Goodyer et al., in a naturalistic treatment study, found no additional positive effects associated with CBT compared with fluoxetine only (e13). Fluvoxamine is indicated from the 8th year of life, but for compulsive disorders. Sertraline also seems to have a positive effect in adolescents, according to recent research (e14, e15). Further studies promise data for more evidence-based therapeutic interventions in the future. In spite of an extremely low level of evidence (V), Saint John's wort is the substance most often prescribed for adolescents in Germany (18).
After the necessary routine investigations, antidepressants should be introduced in small steps at 4 to 7 day intervals. The time at which they should be administered depends on whether a sedative or stimulant preparation was selected; because of the long half life of modern antidepressants, one daily dose is sufficient (with very few exceptions, such as fluvoxamine) in patients with a normal metabolism. The drugs need to be taken at regular intervals and continually, for about six months after the symptoms have subsided (e7). Stopping abruptly is associated with the risk of activation syndrome, and patient and relatives will need to be warned explicitly.

\section{Conclusion}

Cognitive behavioral therapy and interpersonal therapy in children and adolescents are supported by good evidence (level I and II). For pharmacotherapy it has to be remembered that fluoxetine is currently the only evidencebased pharmacotherapeutic option for minors from the age of 8 , and sertraline presumably is of similar efficacy in youngsters. However, in the individual case, treatment with another SSRI may be of benefit. In any case, drug treatment should be embedded in comprehensive therapy from a child and adolescent psychiatrist.

\section{Conflict of interest statement}

The authors declare that no conflict of interest exists according to the guidelines of the International Committee of Medical Journal Editors.

Manuscript received on 5 September 2007, revised version accepted on 28 November 2007.

Translated from the original German by Dr Birte Twisselmann

\section{REFERENCES}

1. Van Engeland H: Suizidales Verhalten in der Adoleszenz. In: Freisleder FJ, Schlamp D, Naber G (eds.): Depression, Angst, Suizidalität. Affektive Störungen im Kindes- und Jugendalter. München: Zuckschwerdt 2001; 47-54

2. Blanz B, Remschmidt H, Schmidt MH, Warnke A: Psychische Störungen im Kindes- und Jugendalter. Stuttgart, New York: Schattauer 2006; 357-63.

3. Aldenhoff J: Reflections on the psychobiology of depression. Nervenarzt 1997; 68: 379-89.

4. Schulte-Markwort M, Forouher N: Affektive Störungen. In: HerpertzDahlmann B, Resch F, Schulte-Markwort M, Warnke A (eds.): Entwicklungspsychiatrie. Stuttgart, New York: Schattauer 2003; 609-36.

5. Nemeroff CB: Recent advances in the neurobiology of depression. Psychopharmacology Bulletin 2002; 36 (Suppl. 2): 6-23.

6. Duman RS, Malberg J, Thome J: Neural plasticity to stress and antidepressant treatment. Biol Psychiatry 1999; 46: 1181-91.

7. Birmaher B, Ryan ND, Williamson DE et al.: Childhood and adolescent depression: a review of the past ten years. J Am Acad Child Adolesc Psychiatry 1996; 35: 1427-39.

8. Goodyer IM, Herbert J, Altham PM, Pearson J, Secher SM, Shiers HM: Adrenal secretion during major depression in 8- to 16-year olds. Psychol Med 1996; 11: 545-65.

9. DeBellis MD, Dahl RE, Perel JM et al.: Nocturnal ACTH, cortisol, growth hormone, and prolactin secretion in prepubertal depression. J Am Acad Child Adolesc Psychiatry 1996; 35: 1130-8.

10. Kramer MS, Cutler N, Feighner J et al.: Distinct mechanism for antidepressant activity by blockade of central substance P receptors. Science 1998; 281: 1640-5. 
11. Steingard RJ, Renshaw PF, Yurgelun-Todd D et al.: Structural abnormalities in brain magnetic resonance images of depressed children. J Am Acad Child Adolesc Psychiatry 1996; 35: 307-11.

12. Kimbrell TA, Ketter TA, George MS et al.: Regional cerebral glucose utilization in patients with a range of severities of unipolar depression. Biol Psychiatry 2002; 51: 237-52.

13. Emslie GJ, Weinberg WA, Kennard BD, Kowatch RA: Neurobiological aspects of depression in children and adolescents. In: Reynolds WM, Johnston HF (eds.): Handbook of depression in children and adolescents. New York: Plenum 1994.

14. Essau CA, Petermann U: Depression. In: Petermann F (ed.): Lehrbuch der Klinischen Kinderpsychologie und -psychotherapie (4th edition). Göttingen: Hogrefe 2000; 291-322.

15. Herpertz-Dahlmann B, Remschmidt H: Störungen der Kind-UmweltInteraktion und ihre Auswirkungen auf den Entwicklungsverlauf. In: Petermann F, Niebank K, Scheithauer H (eds.): Risiken in der frühkindlichen Entwicklung. Entwicklungspsychopathologie der ersten Lebensjahre. Göttingen: Hogrefe 2000; 224-38.

16. Eley TC, Stevenson J: Specific life-events and chronic experiences differentially associated with depression and anxiety in young twins. J Abnorm Child Psychol 2000; 28: 383-94.

17. Remschmidt H, Schmidt M, Poustka F (eds.): Multiaxiales Klassifikationsschema für psychische Störungen des Kindes- und Jugendalters nach ICD-10 und WHO. (4th edition). Bern: Hans Huber 2000

18. Kölch M, Fegert JM: Medikamentöse Therapie der Depression bei Minderjährigen. Praxis der Kinderpsychologie und Kinderpsychiatrie 2007; 56: 224-33.

19. Deutsche Gesellschaft für Kinder- und Jugendpsychiatrie und Psychotherapie, Berufsverband der Ärzte für Kinder- und Jugendpsychiatrie und Psychotherapie in Deutschland e. V., Bundesarbeitsgemeinschaft der leitenden Klinikärzte für Kinder- und Jugendpsychiatrie und Psychotherapie e. V. In: Warnke A, Lehmkuhl G (eds.): Leitlinien zur Diagnostik und Therapie von psychischen Störungen im Säuglings-, Kindes- und Jugendalter. Köln: Deutscher Ärzte-Verlag 2006; 57-72.

20. Gerlach M, Rothenhöfer S, Mehler-Wex $C$ et al.: Therapeutisches Drug-Monitoring in der Kinder- und Jugendpsychiatrie - Grundlagen und praktische Empfehlungen. Z Kinder Jugendpsychiatr Psychother 2006; 1: 5-12.

21. Safer DJ, Zito JM: Treatment-emergent adverse events from selective serotonin reuptake inhibitors by age group: children versus adolescents. J Child Adolesc Psychopharmacol 2006; 16 : 159-69.

22. Hammad TA, Laughren T, Racoosin J: Suicidality in pediatric patients treated with antidepressant drugs. Arch Gen Psychiatry 2006; 63: 332-9.

23. The Treatment for Adolescents with Depression Study (TADS) Team: Fluoxetine, cognitive-behavioral therapy, and their combination for adolescents with depression: treatment for adolescents with depression study (TADS) randomized controlled trial. JAMA 2004; 292: 807-20.

24. Emslie GJ, Rush Aj, Weinberg WA: A double-blind randomized placebo-controlled trial of fluoxetine in children and adolescents with depression. Arch Gen Psychiatry 1997; 54: 1031-7.

25. Wewetzer C, Warnke A, Gerlach M: Antidepressiva. In: Gerlach M, Warnke A, Wewetzer Ch (eds.): Neuro-Psychopharmaka im Kindes und Jugendalter. Grundlagen und Therapie. Wien: Springer 2004; 69-93.

Corresponding author

Prof. Dr. med. Claudia Mehler-Wex

Klinik für Kinder- und Jugendpsychiatrie/Psychotherapie

Universität UIm

Steinhövelstr. 5

89075 Ulm, Germany

claudia.mehler-wex@uniklinik-ulm.de 


\title{
REVIEW ARTICLE
}

\section{Depression in Children and Adolescents}

\author{
Claudia Mehler-Wex, Michael Kölch
}

\section{E-REFERENCES}

e1. Little CA, Williams SE, Puzanovova M, Rudzinski ER, Walker LS: Multiple somatic symptoms linked to positive screen for depression in pediatric patients with chronic abdominal pain. J Pediatric Gastroenterol Nutrition 2007; 44: 58-62.

e2. Gibbons RD, Brown CD, Hur K et al.: Early evidence on the effects of regulators' suicidality warnings on SSRI prescriptions and suicide in children and adolescents. Am J Psychiatry 2007, 164: 9: 356-63.

e3. Rübenach SP: Todesursache Suizid, Statistisches Bundesamt Wirtschaft und Statistik 10/2007, http://www.destatis.de/jetspeed/ portal/cms/Sites/destatis/Internet/DE/Content/Publikationen/ Querschnittsveroeffentlichungen/WirtschaftStatistik/ AktuellSuizid, property=file.pdf.

e4. Agerbo E, Nordentoft M, Mortensen PB: Familial, psychiatric, and socioeconomic risk factors for suicide in young people: nested case-control study BMJ 2002; 325: 74.

e5. Hautzinger M: Kognitive Verhaltenstherapie bei Depressionen. 6. , überarbeitete Auflage, Weinheim: Psychologie Verlagsunion; 2003

e6. McArdle P: Comments on NICE guidelines for "depression in children and young people". Child Adolescent Mental Health 2007, 12: 66-9.

e7. National Institute for Clinical Excellence: Depression in children and young people: identification and management in primary, community and secondary care. National Clinical Practice Guideline 28, 2005.

e8. Brent DA, Holder D, Kolko D: A clinical psychotherapy trial for adolescent depression comparing cognitive, family, and supportive therapy. Arch Gen Psychiatry 1997; 54: 877-85.

e9. Mufson L, Dorta KP, Wickramaratne P, Nomura Y, Olfson M, Weissman MM: A randomized effectiveness trial of interpersonal psychotherapy for depressed adolescents. Arch Gen Psychiatry. 2004; 61: $577-84$.

e10. Dt. Ges. f. Kinder- und Jugendpsychiatrie und Psychotherapie u.a. (eds.): Leitlinien zur Diagnostik und Therapie von psychischen Störungen im Säuglings-, Kindes- und Jugendalter. 3. überarbeitete Auflage. Köln: Deutscher Ärzte-Verlag, 2007.

e11. Pössel P, Hautzinger M: Effekte pharmakologischer und psychotherapeutischer Interventionen auf Depressionen bei Kindern und Jugendlichen, Z Kinder Jugendpsychiatr Psychother 2006; 34: 243-55.

e12 Bridge JA, lyengar S, Salary CB et al.: Clinical response and risk for reported suicidal ideation and suicide attempts in pediatric antidepressant treatment. JAMA 2007; 297: 1683-96.

e13. Goodyer I, Dubicka B, Wilkinson P et al.: Selective serotonin reuptake inhibitors (SSRIs) and routine specialist care with and without cognitive behaviour therapy in adolescents with major depression: randomised controlled trial. BMJ 2007; 335: 142.

e14. McClure EB, Leibenluff E, Pine DS: Sertraline improves symptoms in children and adolescents with major depressive disorder. Evid Based Ment Health 2004; 7: 10.

e15. Wagner KD, Ambrosini P, Rynn M et al.: Efficacy of sertraline in the treatment of children and adolescents with major depressive disorder: two randomized controlled trials. JAMA 2003; 290: 1033-41. 